\title{
Biology and Management of Nostoc (Cyanobacteria) in Nurseries and Greenhouses ${ }^{1}$
}

\author{
H. Dail Laughinghouse IV, David E. Berthold, Chris Marble, and Debalina Saha²
}

This document provides an overview of the biology and ecology of Nostoc-like cyanobacteria (blue-green algae) in humid soils and discusses methods to manage this weed in nursery environments. Here, we simplify and group all macroscopic, morphologically Nostoc-like taxa into Nostoc. However, what we call Nostoc in the field actually comprises many different genera, such as Aliinostoc, Aulosira, Desmonostoc, Halotia, Isocystis, Mojavia, Nostoc, and Trichormus. Very general comments on management are made because strain-specific properties, such as different degrees of mucilage and pigmentation, may cause variation among each taxon's susceptibility to control methods. It is important to remember that, in the field, the terrestrial algae commonly live as a complex community of several species of cyanobacteria, chlorophytes, and diatoms, and live in associations with fungi, forming lichens.

\section{Description}

Phylum: Cyanobacteria

Class: Cyanophyceae

Subclass: Nostocophycidae
Order: Nostocales

Family: Nostocaceae

Type Species: Nostoc commune Vaucher ex Bornet et Flahault (1888)

Common Names: algae, star jelly, ground boogers, dragon snot, mare's eggs

Nostoc colonies are composed of aggregated and entangled trichomes (chains of cells) that can grow into macroscopic mats and gelatinous colonies, which can be blue-green, yellow-brown, or dark brown in color. Colonies are usually spherical at the beginning of the vegetative stage and are later irregular, foliar, or filiform. Trichomes are uniseriate, unbranched, flexuous, or curved, and always constricted at the cross walls. Vegetative cells are barrel-shaped to cylindrical. Heterocytes (specialized N-fixing cells) are spherical to oval in shape and usually solitary. Akinetes (dormant, non-motile, thick-walled survival cells) are roughly two times the size of the vegetative cell and can be found in rows, usually containing oval or ellipsoidal cells, but are rarely present. Reproduction is usually by motile

1. This document is SS-AGR-431, one of a series of the Agronomy Department, UF/IFAS Extension. Original publication date February 2019. Visit the EDIS website at https://edis.ifas.ufl.edu for the currently supported version of this publication.

2. H. Dail Laughinghouse IV, assistant professor, Agronomy Department, UF/IFAS Ft. Lauderdale Research and Education Center; David E. Berthold, biological scientist III, UF/IFAS Ft. Lauderdale REC; Chris Marble, assistant professor, Environmental Horticulture Department, UF/IFAS Mid-Florida REC; and Debalina Saha, graduate research assistant, Environmental Horticulture Department, UF/IFAS MFREC; UF/IFAS Extension, Gainesville, FL 32611.

The use of trade names in this publication is solely for the purpose of providing specific information. UF/IFAS does not guarantee or warranty the products named, and references to them in this publication do not signify our approval to the exclusion of other products of suitable composition. All chemicals should be used in accordance with directions on the manufacturer's label. Use pesticides safely. Read and follow directions on the manufacturer's label.

The Institute of Food and Agricultural Sciences (IFAS) is an Equal Opportunity Institution authorized to provide research, educational information and other services only to individuals and institutions that function with non-discrimination with respect to race, creed, color, religion, age, disability, sex, sexual orientation, marital status, national origin, political opinions or affiliations. For more information on obtaining other UF/IFAS Extension publications, contact your county's UF/IFAS Extension office. 
hormogonia (motile filaments of cells formed during asexual reproduction) during colonial disintegration and less frequently by akinete germination. Currently, there are more than 300 described species in the genus Nostoc (Komárek 2013).

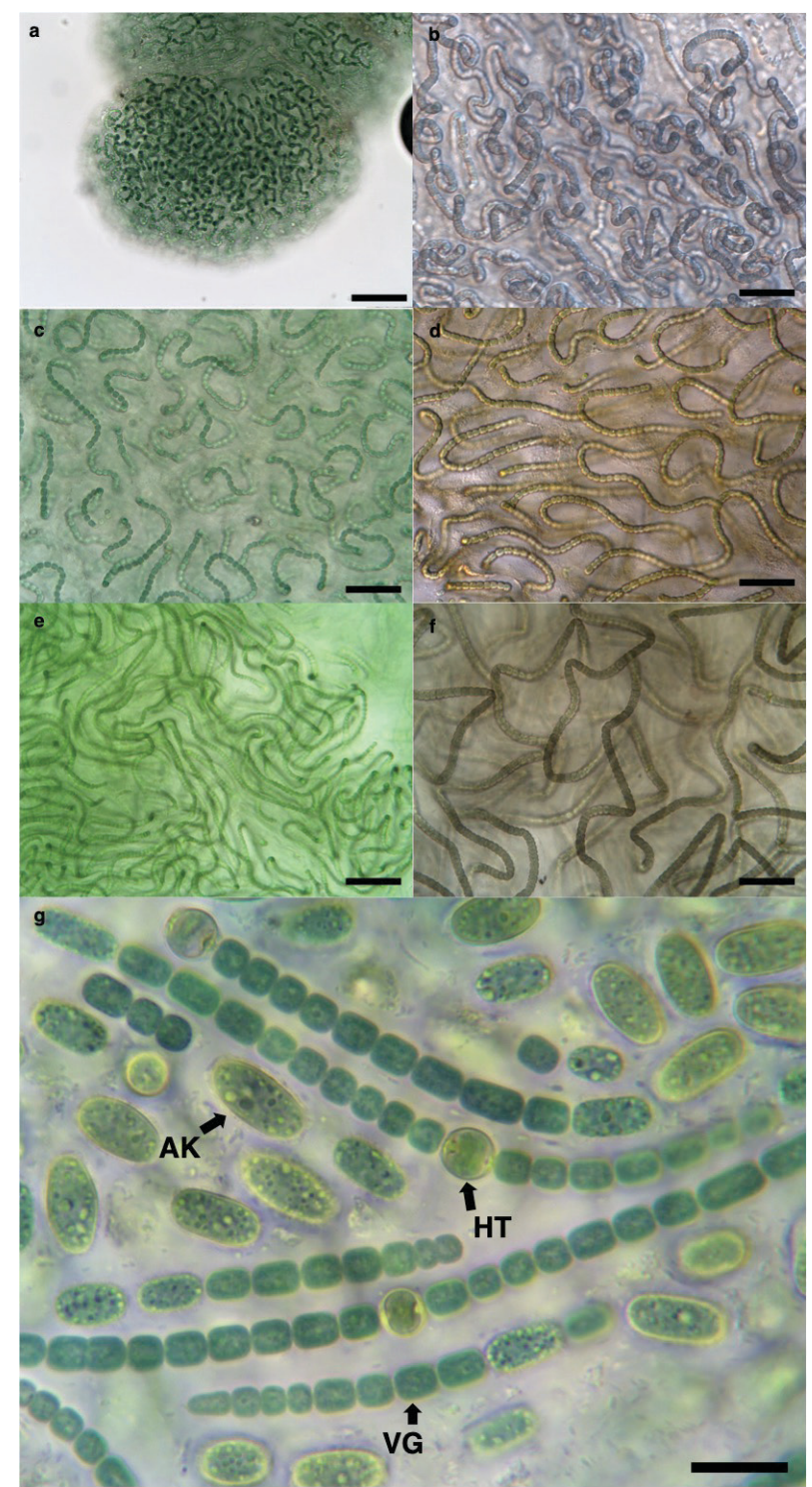

Figure 1. Microscope images of Nostoc indicating a) colony formation within mucilage, b-f) colonies of various morphologies and pigmentation, and g) individual trichomes of cells with heterocytes (HT), vegetative cells (VG), and akinetes (AK). Scale bars represent a) $100 \mu \mathrm{m}, \mathrm{b}-\mathrm{f}) 50 \mu \mathrm{m}$, and g) $20 \mu \mathrm{m}$.

Credits: David E. Berthold, UF/IFAS

\section{Habitat and Distribution}

Nostoc-like blue-green algae are among the most common and widespread cyanobacteria in moist substrate environments. Species of this group are aquatic, subaerophytic, endobiotic, symbiotic, and/or terrestrial. They occur in tropical, temperate, and polar environments and are commonly found on gravel, ground cloths, aisles, and countless other production areas of nurseries and greenhouses.

\section{Biology}

Nostoc-like cyanobacteria grow on the surface of soil, gravel, cement, and even plastic containers, producing macroscopic mats.

These mats desiccate and become flaky during dry periods, but in the presence of water or any moisture, they swell to form thick, dark green, gelatinous masses that can completely cover container production areas. This taxon is unsightly, but more importantly, it is extremely slippery and wet. This poses serious health hazards to nursery employees. Another concern is their ability to produce cyanotoxins and allelopathic compounds (Kleinteich et al. 2018), which can affect plant growth and physiology. Although cyanobacterial mats can be a nuisance, they are an important component of soils due to their water-holding capacity and ability to fix atmospheric nitrogen and sequester carbon into soils (Sangeetha et al. 2013; Singh et al. 2016). Also, certain Nostoc species can form symbiotic relationships with plants (e.g., N. cycadeae A.M.Watanabe et Kiyohara) or fungi to form lichens (e.g., N. lichenoides Vaucher ex Řeháková et Johansen). Furthermore, the species N. ellipsosporum Rabenhorst ex Bornet et Flahault has been found to produce a protein called cyanovirin-N, with antiviral activities against HIV (human immunodeficiency virus), FIV (feline immunodeficiency virus), and herpes (Dey et al. 2000).

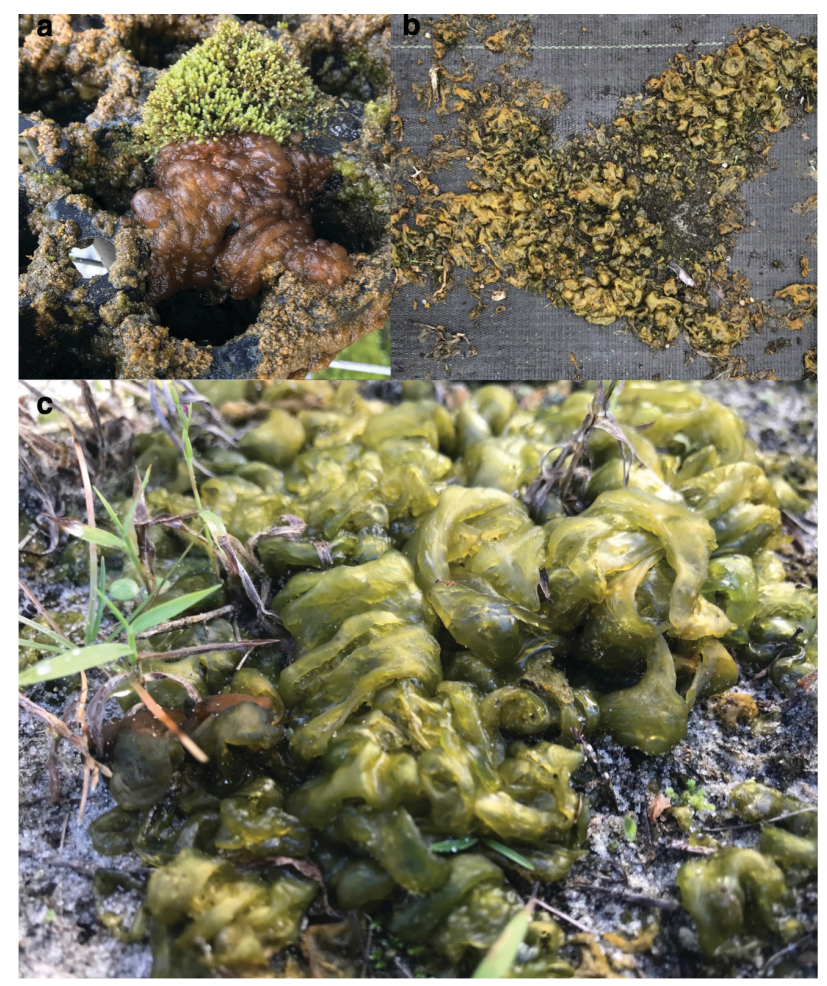

Figure 2. Images of Nostoc macroscopic colonies commonly found in the field on a) plastic containers, b) greenhouse tarp, and c) sandy and limestone ground.

Credits: David E. Berthold, UF/IFAS 


\section{Management}

Nostoc-like cyanobacteria can enter nurseries and greenhouses via foot traffic, gardening tools, aerial transport, or irrigation systems that use water contaminated with algae. Once in a greenhouse, they can grow quickly and produce large biomass due to nutrients from fertilizers and irrigation, light, high humidity, and warm temperatures (Latimer et al. 1996).

\section{Cultural and Physical Control}

Increasing drainage and reducing overhead irrigation can decrease the occurrence of Nostoc-like cyanobacteria, but these may not be possible in every situation. Some nurseries have had success in physically removing the cyanobacteria through raking or allowing the area to dry and using blowers to blow it out of production areas. These methods provide only short-term control because these algae will eventually return. In non-crop areas, such as walkways between container pads, nurseries have reported successful management following planting of bahiagrass (Paspalum notatum Flueggé) in areas previously left bare. Using bahiagrass or other ground covers can lower the amount of standing water on the soil surface and reduce the abundance of Nostoc by competition. Use of solarization or flame weeders has also been effective in some cases (Parke and Stoven 2014).

\section{Chemical Control}

Few reports on Nostoc response to chemical control strategies are available. Results are also variable from study to study, with authors often reporting different results for the same treatments. This is likely due to variation among the Nostoc-like species or genera evaluated in different studies.

Research is being conducted at the University of Florida Institute of Food and Agricultural Sciences (UF/IFAS) to determine effective Nostoc management methods. Our research in the field and with Nostoc commune in the lab showed that chemical efficacy depends on the chemical and the surface on which the chemical is applied. Effective treatments on gravel surfaces have included Zerotol 2.0 (hydrogen peroxide + peroxyacetic acid), TerraCyte PRO (sodium carbonate peroxyhydrate), and generic germicidal bleach. On plastic tarps, effective treatments have included TerraCyte PRO, germicidal bleach, and Scythe (pelargonic acid). Scythe has also been reported to be effective in other trials (Parke and Stoven 2014). Copper sulfate, which has been suggested as a possible solution but has not been labeled for ground application, actually stimulated growth in research trials.
When applied at recommended high label rates, the most effective chemical option for management was TerraCyte PRO. However, Zerotol 2.0, germicidal bleach, and Scythe were also effective in some instances. Depending on the species of Nostoc (or other morphologically similar genera), other options may also be effective. In many cases, follow-up applications will be needed for complete control. All of these products are labeled for use in nursery and greenhouse production areas.

Follow label instructions when using products. Safety equipment required on the label and by federal or state law should be used. Pesticide registrations may change, so it is the responsibility of the user to ascertain if a pesticide is registered by the appropriate state and federal agencies for its intended use.

\section{References}

Dey, B., D. L. Lerner, P. Lusso, M. R. Boyd, J. H. Elder, and E. A. Berger. 2000. "Multiple antiviral activities of cyanovirin-N: Blocking of human immunodeficiency virus type 1 gp120 interaction with CD4 and coreceptor and inhibition of diverse enveloped viruses." Journal of Virology 74(10): 4562-4569. https://doi.org/10.1128/ JVI.74.10.4562-4569.2000

Kleinteich, J., J. Puddick, S. A. Wood, F. Hildebrand, H. D. Laughinghouse IV, D. A. Pearce, D. R. Dietrich, and A. Wilmotte. 2018. "Toxic cyanobacteria in Svalbard: Chemical diversity of microcystins detected using a liquid chromatography mass spectrometry precursor ion screening method." Toxins 10: e147. https://doi.org/10.3390/ toxins 10040147

Komárek, J. 2013. "Cyanoprokaryota 3. Heterocytous genera." In Sübwasserflora Von Mitteleuropa/Freshwater Flora of Central Europe, edited by G. Gärtner, L. Krienitz, and M. Schagerl. 1130. Heidelberg: Springer.

Latimer, J. G., R. B. Beverly, C. D. Robacker, O. M. Lindstrom, R. D. Oetting, D. L. Olson, S. K. Braman, et al. 1996. "Reducing the pollution potential of pesticides and fertilizers in the environmental horticulture industry: I. Greenhouse, nursery, and sod production." HortTechnology 6(2): 115-124.

Parke, J., and H. Stoven 2014. "Management of the cyanobacterium Nostoc in horticultural nurseries." Digger 58: 25-29. 
Sangeetha, B. M., S. Aarthi, R. Niranjana, and R. V. Lakshmi. 2013. "Role of cyanobacteria and Azolla in inorganic carbon sequestration and nutrients enrichment in soil." International Journal of Engineering Research \& Technology 2(6): 2130-2137.

Singh, J. S., A. Kumar, A. N. Rai, and D. P. Singh. 2016. "Cyanobacteria: a precious bio-resource in agriculture, ecosystem, and environmental sustainability." Frontiers in Microbiology 7: 529. https://doi.org/10.3389/

fmicb.2016.00529 